\title{
Diversity of Odonata (Insecta) larvae in streams and farm ponds of a montane region in southern Brazil
}

\author{
Mateus Marques Pires ${ }^{1,5}$, Carla Bender Kotzian², Marcia Regina Spies ${ }^{3}$ \& Damaris Battistel Neri ${ }^{4}$ \\ ${ }^{1}$ Programa de Pós-graduação em Biologia, Universidade do Vale do Rio dos Sinos - UNISINOS, \\ Av. Unisinos, 950, CEP 93022-000, São Leopoldo, RS, Brasil \\ ${ }^{2}$ Programa de Pós-graduação em Biodiversidade Animal, Departamento de Biologia, \\ Centro de Ciências Naturais e Exatas, Universidade Federal de Santa Maria-UFSM, \\ Av. Roraima, 1000, CEP 97015-900, Santa Maria, RS, Brasil \\ ${ }^{3}$ Universidade Federal do Pampa - UNIPAMPA, Av. Antônio Trilha, 1847, \\ CEP 97300-000, São Gabriel, RS, Brasil \\ ${ }^{4}$ Instituto Pró-Universidade Canoense, Av. Guilherme Schell, 5000, CEP 92310-000, Canoas, RS, Brasil \\ ${ }^{5}$ Corresponding author: Mateus Marques Pires, e-mail: marquespiresm@gmail.com
}

PIRES, M.M., KOTZIAN, C.B., SPIES, M.R. \& NERI, D.B. Diversity of Odonata (Insecta) larvae in streams and farm ponds of a montane region in southern Brazil. Biota Neotrop. (13)3:http://www.biotaneotropica. org.br/v13n3/en/abstract?inventory+bn01813032013

Abstract: This study presents an inventory of the genera of Odonata found in streams and artificial farm ponds in a montane region, with temperate climate, in southern Brazil. Differences in richness of lotic and lentic environments were also investigated. The diversity of odonate families and genera in southernmost Brazil is lower than in warmer, either tropical or subtropical, regions of the country. Nine genera are new records for the region and six genera had their geographical ranges extended to regions with temperate climate of the Neotropics. The overall richness and especially the overall abundance recorded in the studied area are possibly determined by the occurrence of numerous farm ponds because natural standing waters are scarce in the region. The presence of macrophytes in these artificial ponds allowed the establishment of a diversified odonatofauna, typical of lentic environments. Keywords: dragonfly, inventory, Neotropical region, reservoirs, riverine fauna.

PIRES, M.M., KOTZIAN, C.B., SPIES, M.R. \& NERI, D.B. Diversidade de larvas de Odonata (Insecta) em riachos e açudes de uma região montanhosa no sul do Brasil. Biota Neotrop. (13)3:http://www.biotaneotropica. org.br/v13n3/pt/abstract?inventory+bn01813032013

Resumo: Este estudo apresenta um inventário de gêneros de Odonata de riachos e reservatórios artificiais de uma região montanhosa de clima temperado no extremo sul do Brasil. Diferenças na riqueza de ambientes lóticos e lênticos também foram investigadas. A diversidade de famílias e gêneros de Odonata no extremo sul do Brasil é menor que em regiões mais quentes, tanto tropicais quanto subtropicais, do país. Nove gêneros são novos registros para a região e seis gêneros tiveram suas distribuições geográficas de ocorrência estendidas para áreas temperadas da região Neotropical. A riqueza e a abundância verificadas na área de estudo possivelmente foram determinadas pela ocorrência de numerosos reservatórios artificiais, pois áreas lênticas naturais são raras na região. A presença de macrófitas nestes reservatórios permitiu o estabelecimento de uma fauna de Odonata diversificada e típica de ambientes lênticos.

Palavras-chave: libélulas, inventário, região Neotropical, reservatórios, fauna lótica. 


\section{Introduction}

Odonate larvae occupy a variety of running and standing freshwater environments such as rivers, lakes, ponds, wetlands and, to a lesser extent, phytotelma, brackish waters and rithral areas of rivers (Merritt \& Cummings 1996, Souza et al. 2007). In these habitats, they play an important role in ecological food webs, feeding on smaller insects, including fingerlings and young tadpoles, or serving as prey for adult fishes (Corbet 1999). Additionally, they are also efficient indicators of water quality (Ferreira-Peruquetti \& De Marco Junior 2002), due to the preference of both larval and adult stages for certain environmental conditions for their establishment (Corbet 1999, Clausnitzer et al. 2009). Odonate larvae may also occur in artificial water bodies (e.g., reservoirs), but their diversity in such environments is little studied (Williams et al. 2008)

Odonates, as other aquatic animal groups, have been threatened by human activities. About $10 \%$ of odonate species worldwide are considered "threatened", $35 \%$ are classified as "data deficient", and $6 \%$ are "endangered" (Clausnitzer et al. 2009). However, the diversity of odonates is not well known in certain regions of the world. According to Kalkman et al. (2008) 1,000 to 1,500 species are yet to be described. In Brazil, which occupies ca. of $50 \%$ of the area of the Neotropics, only 800 species have been reported (Souza et al. 2007). Besides, the occurrence of odonates has been documented in less than one-third of the Brazilian territory, and especially in areas with tropical and subtropical climates (De Marco Junior \& Vianna 2005). Additionally, bioecological studies have focused mainly on lakes and floodplains (De Marco Junior \& Latini 1998, Franco \& Takeda 2002, Fulan \& Henry 2006, 2007, Juen et al. 2007, Giacomini \& De Marco Junior 2008), while main channels of lowland rivers (Ferreira-Peruquetti \& De Marco Junior 2002, Assis et al. 2004), montane streams (Dalzochio et al. 2011), wetlands (Maltchik et al. 2010), reservoir and fishfarms (De Marco Junior et al. 1999, Fonseca et al. 2004) are poorly known.

The state of Rio Grande do Sul (RS) has temperate climate, but winters are not rigorous and the annual rainfall is constant (Brasil 1986). These conditions may allow the presence of a diversified odonatofauna (Kalkman et al. 2008). In fact, some studies have suggested that in regions with temperate climate, certain groups of riverine macroinvertebrates may have greater richness than in regions with tropical climate (e.g., McKie et al. 2005; see Floss et al. 2012 for southern Brazil). In RS, many watersheds run from highlands to lowlands, and therefore show different substrate composition, a factor that also contributes for the occurrence of a diversified macroinvertebrate composition (Beisel et al. 2000, Voelz \& McArthur 2000). Additionally, the slopes have relatively well preserved landscapes (Marcuzzo et al. 1998).

The knowledge on the diversity of odonates in RS is incipient. Inventories of adult individuals (Costa 1971, Teixeira 1971) and larvae from wetland systems (Maltchik et al. 2010) constitute the only references for the order, and inventories in lotic environments are missing. The occurrence of small reservoirs along streams is too common, and must contribute to the establishment of a typical fauna of lentic environments, along the stream banks. This study presents an inventory of the genera of odonate larvae found in streams and artificial farm ponds, in the middle course of the Jacuí River. This river runs in a montane region which contains a well diversified macroinvertebrate community (see Neri et al. 2005 for Heteroptera; Spies et al. 2006 for Trichoptera; Siegloch et al. 2008 for Ephemeroptera; Floss et al. 2012, for Chironomidae). Differences in the community structure of lotic and lentic environments were also investigated, in order to contribute to the initial understanding of the importance and influence of reservoirs on odonates biodiversity.

\section{Material and Methods}

\section{Study area}

The middle course of the Jacuí River basin is one of the most important watersheds of the Rio Grande do Sul state, in southernmost Brazil (Figure 1). The basin is $800 \mathrm{~km}$ long and covers $71,600 \mathrm{~km}^{2}$ (Zamanillo et al. 1989). In October 2000, the middle reach of the Jacuí River was dammed at its downstream end, for hydroelectric purposes (Dona Francisca Power Station, UHEDF, 29²6’50" S and $53^{\circ} 16^{\prime} 50^{\prime}$ 'W) (Figure 1). Nowadays, part of the area nearby the UHEDF reservoir comprehends the 'Parque Estadual da Quarta Colônia'.

The middle Jacuí River runs over a mountainous region (the Encosta Inferior do Nordeste), with altitudes ranging from 50 to $500 \mathrm{~m}$. The river valley is deep and narrow, not favoring for the existence of large agricultural areas (Marchiori et al. 1982). The numerous rivers and streams of the region have predominantly gravelly beds (boulders and cobbles). Lentic environments such as marshes and lakes are absent, and few backwaters are found only downstream, near the lowlands in the lower part of the middle course. However, small reservoirs and artificial farm ponds used to water livestock are very common.

The original vegetation of the region was the Seasonal Deciduous Forest, which was mostly deforested after colonization by immigrants in the XIX ${ }^{\text {th }}$ century. Nowadays, this forest is represented only by small fragments, and second growth and riparian forests are

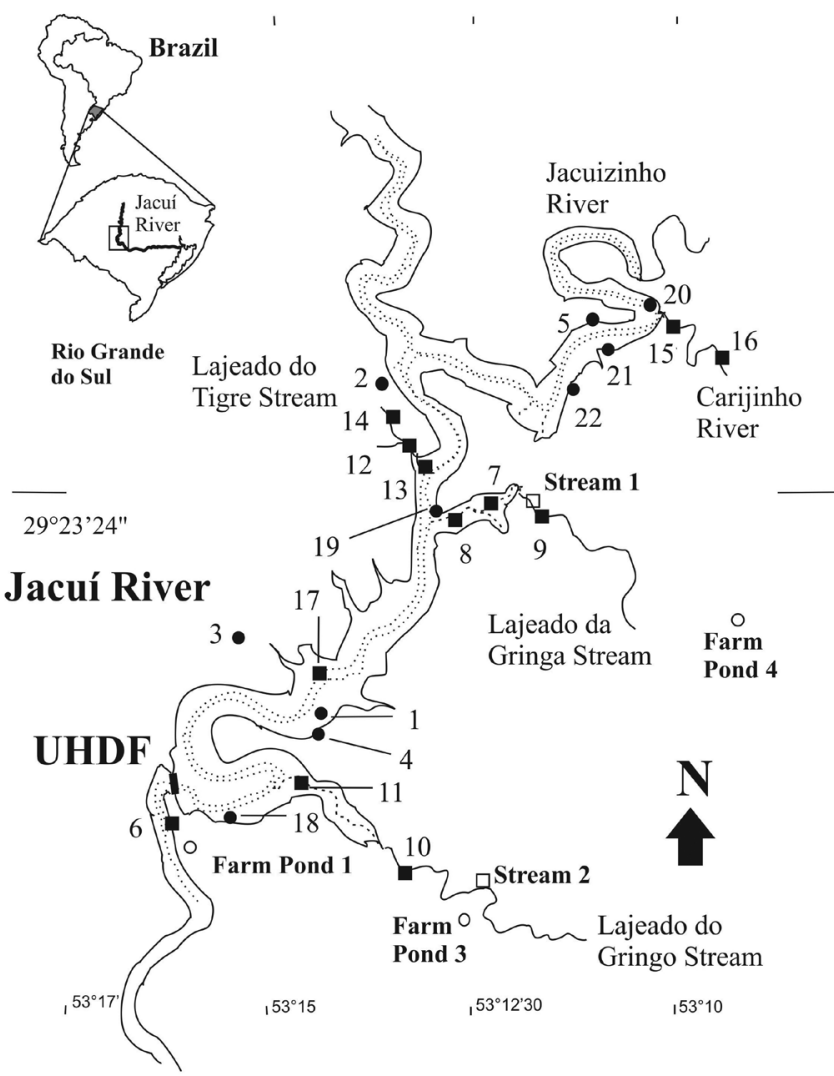

Figure 1. Location of studied sites in the middle course of the Jacuí River basin, central region of the State of Rio Grande do Sul, Brazil. Squares indicate lotic sites and circles, lentic ones. Filled figures represent sites sampled from April through October 2000 and from June 2001 through May 2002 and empty ones, between January 2008 and February 2009. Dotted line represents the course of the Jacuí River and its tributaries before UHEDF impoundment. 
distributed sparsely along rivers and on mountain slopes (Durlo et al. 1982, Longhi et al. 1982, Marchiori et al. 1982, Marcuzzo et al. 1998). Land use consists mainly of small farms, used for livestock and some fruits and vegetables. Maize and tobacco are the most common major crops in the region (Rio Grande do Sul 2013).

The climate of the region is $\mathrm{Cfa}$, according to the Köppen classification (Durlo et al. 1982, Maluf 2000). The mean annual temperature ranges from 18 to $22{ }^{\circ} \mathrm{C}$, nearing $13{ }^{\circ} \mathrm{C}$ during the coldest period of the year (Maluf 2000). This is the lowest minimum temperature in the country (Brasil 1986), and leads some authors to consider the climate as temperate (Maluf 2000). Rainfall is distributed evenly through the year, with the total annual precipitation ranging from 1,500 to $1,750 \mathrm{~mm}$ (Pereira et al. 1989).

Table 1. Location of the qualitative sampling sites of larval odonate genera in the area of scope of UHEDF, middle course of the Jacuí River basin, Rio Grande do Sul State, Brazil. Sites 6, 9,11 and 16 were also sampled in the post-impoundment phase of UHEDF.

\begin{tabular}{|c|c|c|}
\hline Site & Environment & Coordinates \\
\hline \multicolumn{3}{|c|}{$\begin{array}{c}\text { Pre-impoundment period } \\
\text { (January } 2000 \text { through October 2000) }\end{array}$} \\
\hline 1 & lentic & $29^{\circ} 25^{\prime} 48 \mathrm{~S} 53^{\circ} 15^{\prime} 08 \mathrm{~W}$ \\
\hline 2 & lentic & $29^{\circ} 21^{\prime} 14 \mathrm{~S} 53^{\circ} 14^{\prime} 03 \mathrm{~W}$ \\
\hline 3 & lentic & $29^{\circ} 25^{\prime} 30 \mathrm{~S} 53^{\circ} 15^{\prime} 39 \mathrm{~W}$ \\
\hline 4 & lentic & $29^{\circ} 26^{\prime} 09 \mathrm{~S} 53^{\circ} 15^{\prime} 09 \mathrm{~W}$ \\
\hline 5 & lentic & $29^{\circ} 20^{\prime} 43 \mathrm{~S} 53^{\circ} 10^{\prime} 57 \mathrm{~W}$ \\
\hline 6 & lotic & $29^{\circ} 28^{\prime} 44 \mathrm{~S} 53^{\circ} 16^{\prime} 56 \mathrm{~W}$ \\
\hline 7 & lotic & $29^{\circ} 23^{\prime} 01 \mathrm{~S} 53^{\circ} 12^{\prime} 34 \mathrm{~W}$ \\
\hline 8 & lotic & $29^{\circ} 23^{\prime} 01 \mathrm{~S} 53^{\circ} 13^{\prime} 19 \mathrm{~W}$ \\
\hline 9 & lotic & $29^{\circ} 22^{\prime} 57 \mathrm{~S} 53^{\circ} 12^{\prime} 08 \mathrm{~W}$ \\
\hline 10 & lotic & $29^{\circ} 28^{\prime} 03 \mathrm{~S} 53^{\circ} 13^{\prime} 28 \mathrm{~W}$ \\
\hline 11 & lotic & $29^{\circ} 28^{\prime} 07 \mathrm{~S} 53^{\circ} 13^{\prime} 28 \mathrm{~W}$ \\
\hline 12 & lotic & $29^{\circ} 22^{\prime} 16 \mathrm{~S} 53^{\circ} 13^{\prime} 41 \mathrm{~W}$ \\
\hline 13 & lotic & $29^{\circ} 22^{\prime} 26 \mathrm{~S} 53^{\circ} 13^{\prime} 37 \mathrm{~W}$ \\
\hline 14 & lotic & $29^{\circ} 21^{\prime} 53 \mathrm{~S} 53^{\circ} 14^{\prime} 07 \mathrm{~W}$ \\
\hline 15 & lotic & $29^{\circ} 20^{\prime} 32 \mathrm{~S} 53^{\circ} 09^{\prime} 57 \mathrm{~W}$ \\
\hline 16 & lotic & $29^{\circ} 21^{\prime} 26 \mathrm{~S} 53^{\circ} 09^{\prime} 11 \mathrm{~W}$ \\
\hline 17 & lotic & $29^{\circ} 25^{\prime} 21 \mathrm{~S} 53^{\circ} 14^{\prime} 51 \mathrm{~W}$ \\
\hline \multicolumn{3}{|c|}{$\begin{array}{c}\text { Post-impoundment period } \\
\text { (May } 2001 \text { through October 2002) }\end{array}$} \\
\hline 18 & lentic & $29^{\circ} 26^{\prime} 44 \mathrm{~S} 53^{\circ} 16^{\prime} 50 \mathrm{~W}$ \\
\hline 19 & lentic & $29^{\circ} 23^{\prime} 28 \mathrm{~S} 53^{\circ} 13^{\prime} 54 \mathrm{~W}$ \\
\hline 20 & lentic & $29^{\circ} 20^{\prime} 12 \mathrm{~S} 53^{\circ} 14^{\prime} 02 \mathrm{~W}$ \\
\hline 21 & lentic & $29^{\circ} 20^{\prime} 44 \mathrm{~S} 53^{\circ} 10^{\prime} 19 \mathrm{~W}$ \\
\hline 22 & lentic & $29^{\circ} 21^{\prime} 45 \mathrm{~S} 53^{\circ} 11^{\prime} 38 \mathrm{~W}$ \\
\hline
\end{tabular}

\section{Sampling methods}

Sampling was conducted monthly, from March 2008 to February 2009, at six sites represented by two streams and four farm ponds (Figure 1, Table 2). All farm ponds except Pond 4 are permanent, with muddy bottoms and ca. $1 \mathrm{~m}$ deep, and are used to water cattle. In both lentic and lotic environments, samples were taken with hand sieves (mesh $=1 \mathrm{~mm})$, with a sampling effort of 1 hour by one person, never exceeding $1 \mathrm{~m}$ depth, and was mostly conducted along the banks. Qualitative sampling of adults was also conducted monthly, with a hand net at all six sites, in order to corroborate and/or assist in larvae identification. Additionally, specimens qualitatively collected during the pre-impoundment (January 2000 through October 2000) and post-impoundment (May 2001 through October 2002) phases of the construction of the UHEDF reservoir were also included in the overall inventory. These larvae were collected at irregular intervals, using different and not standardized sampling methods, in 12 sites located in rivers and streams and in 10 artificial farm ponds (Figure 1, Table 1).

The specimens collected were fixed and preserved in $70 \%$ ethyl alcohol. Larvae and adults were identified to genus level, using specialized keys (Carvalho \& Calil 2000 and Costa et al. 2004 for larvae; and Garrison et al. 2006 and Lencioni 2005, 2006 for adults) and with the collaboration of specialists. Voucher specimens are deposited in the Invertebrate Collection (UFSM-AI 2551 to 2800), Biology Department, Federal University of Santa Maria (UFSM), State of Rio Grande do Sul, Brazil.

\section{Data analysis}

Based on the quantitative samplings (2008-2009), the accumulated richness of the genera was estimated by the collector's curve, which was obtained with 500 curves generated by random addition of samples using EstimateS 8.2 software (Colwell 2009). Rarefaction curves were constructed in order to estimate the richness of genera of lotic and lentic environments, based on Hurlbert (1971) and Simberloff (1972). Through this method, the estimated richness is compared, using the smallest abundance level among the assemblages (Gotelli \& Entsminger 2006). The mean rarefaction curves were estimated based on 1,000 iterations, using the program EcoSim version 7.72 (Gotelli \& Entsminger 2006).

\section{Results}

A total of 2,939 larvae attributed to 30 genera and seven families were recorded between March 2008 and February 2009 (Table 3). The cumulative curve of genera for this period did not present stability, indicating that the asymptote was not reached (Figure 2). Acanthagrion Selys, 1876 (28.4\%), Lestes Leach, 1815 (21.6\%), Erythrodiplax Brauer, 1868 (13.6\%), and Oxyagrion Selys, 1876

Table 2. Location and characterization of the sampling sites of larval odonate genera in the quantitative period of sampling (March 2008 through February 2009), in the middle course of the Jacuí River basin, Rio Grande do Sul State, Brazil.

\begin{tabular}{|c|c|c|c|c|c|c|}
\hline Site & Coordinates & $\begin{array}{c}\text { Marginal } \\
\text { vegetation }\end{array}$ & $\begin{array}{c}\text { Macrophyte } \\
\text { richness }\end{array}$ & Shading & Area $\left(m^{2}\right)$ & Order \\
\hline Lajeado da Gringa Stream & $29^{\circ} 22^{\prime} 58 \mathrm{~S} 53^{\circ} 12^{\prime} 11 \mathrm{~W}$ & - & - & Yes & - & third \\
\hline Lajeado do Gringo Stream & $29^{\circ} 28^{\prime} 05 \mathrm{~S} 53^{\circ} 13^{\prime} 30 \mathrm{~W}$ & - & - & Partial & - & fourth \\
\hline Farm Pond 1 & $29^{\circ} 27^{\prime} 30 \mathrm{~S} 53^{\circ} 17^{\prime} 30 \mathrm{~W}$ & No & 0 & Yes & 50 & - \\
\hline Farm Pond 2 & 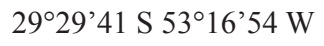 & Yes & 10 & No & 230 & - \\
\hline Farm Pond 3 & $29^{\circ} 28^{\prime} 6 \mathrm{~S} \mathrm{53} 13^{\prime} 23 \mathrm{~W}$ & Yes & 1 & No & 560 & - \\
\hline Farm Pond 4 & $29^{\circ} 25^{\prime} 27 \mathrm{~S} 53^{\circ} 9^{\prime} 1 \mathrm{~W}$ & Yes & 10 & No & 600 & - \\
\hline
\end{tabular}


Table 3. Diversity (families and genera), richness (S), number of specimens $(\mathrm{N})$ and relative abundance (\%) of odonate genera registered in streams and farm ponds in the middle course of the Jacuí River Basin, Rio Grande do Sul State, Brazil, in the quantitative period of sampling (March 2008 through February 2009).

\begin{tabular}{|c|c|c|c|c|c|c|c|c|c|c|}
\hline \multirow[t]{2}{*}{ Sites } & & \multicolumn{3}{|c|}{ Streams } & \multicolumn{6}{|c|}{ Farm Ponds } \\
\hline & & $\begin{array}{c}\text { Lajeado } \\
\text { da Gringa }\end{array}$ & $\begin{array}{c}\text { Lajeado } \\
\text { do Gringo }\end{array}$ & Subtotal & Pond 1 & Pond 2 & Pond 3 & Pond 4 & Subtotal & Total \\
\hline Family & Genera & $\%$ & $\%$ & & $\%$ & $\%$ & $\%$ & $\%$ & & \\
\hline Calopterygidae & Hetaerina Hagen, 1853 & 19.78 & 7.65 & 50 & 0 & 0 & 0 & 0 & $\mathbf{0}$ & 50 \\
\hline \multirow[t]{5}{*}{ Coenagrionidae } & Acanthagrion Selys, 1876 & 15.38 & 7.65 & 42 & 80.41 & 47.73 & 6.93 & 17.16 & 793 & 835 \\
\hline & Argia Rambur, 1842 & 13.73 & 59.56 & 134 & 0 & 0 & 0 & 0 & $\mathbf{0}$ & 134 \\
\hline & Ischnura Charpentier, 1840 & 0 & 0 & $\mathbf{0}$ & 0.51 & 1.17 & 0.93 & 1.19 & 26 & 26 \\
\hline & Oxyagrion Selys, 1876 & 1.09 & 0 & 2 & 1.8 & 26.63 & 14.4 & 5.6 & 321 & 323 \\
\hline & Telebasis Selys, 1865 & 0 & 0 & $\mathbf{0}$ & 0 & 0 & 0.13 & 0 & 1 & 1 \\
\hline Lestidae & Lestes Leach, 1815 & 0 & 0 & $\mathbf{0}$ & 2.57 & 2.01 & 27.33 & 48.74 & 636 & 636 \\
\hline \multirow[t]{4}{*}{ Aeshnidae } & Anax Leach 1815 & 0 & 0 & $\mathbf{0}$ & 0 & 0.16 & 0.13 & 3.57 & 32 & 32 \\
\hline & Castoraeschna Calvert, 1952 & 1.09 & 0.54 & 3 & 0 & 0 & 0 & 0 & $\mathbf{0}$ & 3 \\
\hline & Coryphaeschna Williamson, 1903 & 0 & 0 & $\mathbf{0}$ & 0 & 2.34 & 0 & 0.47 & 18 & 18 \\
\hline & Rhionaeschna Förster, 1909 & 0 & 0 & $\mathbf{0}$ & 0.77 & 0 & 1.46 & 11.2 & 108 & 108 \\
\hline Corduliidae & Navicordulia Machado e Costa, 1995 & 25.27 & 14.75 & 73 & 0 & 0 & 0 & 0 & $\mathbf{0}$ & 73 \\
\hline \multirow[t]{6}{*}{ Gomphidae } & Aphylla Selys, 1854 & 0 & 0 & $\mathbf{0}$ & 0 & 0 & 0.13 & 0.11 & 2 & 2 \\
\hline & Archaeogomphus Williamson, 1919 & 1.09 & 0 & 2 & 0 & 0 & 0 & 0 & $\mathbf{0}$ & 2 \\
\hline & Desmogomphus Williamson, 1920 & 1.09 & 1.63 & 5 & 0 & 0 & 0 & 0 & $\mathbf{0}$ & 5 \\
\hline & Phyllocycla Calvert, 1948 & 14.83 & 2.18 & 31 & 0 & 0 & 0 & 0 & $\mathbf{0}$ & 31 \\
\hline & Progomphus Selys, 1854 & 1.64 & 1.09 & 5 & 0 & 0 & 0 & 0 & $\mathbf{0}$ & 5 \\
\hline & Tibiagomphus Belle, 1992 & 1.09 & 3.27 & 8 & 0 & 0 & 0 & 0 & $\mathbf{0}$ & 8 \\
\hline \multirow[t]{12}{*}{ Libellulidae } & Brechmorhoga Kirby 1894 & 0 & 1.09 & 2 & 0 & 0 & 0 & 0 & $\mathbf{0}$ & 2 \\
\hline & Elasmothemis Westfall, 1988 & 0.54 & 0 & 1 & 0.002 & 0 & 0 & 0 & 1 & 2 \\
\hline & Erythemis Hagen, 1861 & 0 & 0 & $\mathbf{0}$ & 0.51 & 0 & 0 & 0 & 2 & 2 \\
\hline & Erythrodiplax Brauer, 1868 & 2.74 & 0 & 5 & 9.53 & 17.42 & 29.06 & 4.88 & 400 & 405 \\
\hline & Gynothemis Calvert in Ris, 1909 & 0 & 0 & $\mathbf{0}$ & 1.28 & 0 & 0 & 0 & 5 & 5 \\
\hline & Micrathyria Kirby, 1889 & 0 & 0 & $\mathbf{0}$ & 0 & 2.51 & $0 ., 53$ & 0.35 & 22 & 22 \\
\hline & Oligoclada Karsch, 1890 & 0 & 0 & $\mathbf{0}$ & 0.51 & 0 & 0 & 0 & 2 & 2 \\
\hline & Orthemis Hagen, 1861 & 0 & 0 & $\mathbf{0}$ & 0.002 & 0 & 0.13 & 3.93 & 35 & 35 \\
\hline & Pantala Hagen, 1861 & 0 & 0.54 & 1 & 0 & 0 & 0.4 & 1.31 & 14 & 15 \\
\hline & Perithemis Hagen, 1861 & 0 & 0 & $\mathbf{0}$ & 0 & 0 & 0 & 0.47 & 4 & 4 \\
\hline & Tauriphila Kirby, 1889 & 0 & 0 & $\mathbf{0}$ & 0.002 & 0 & 0 & 0 & 1 & 1 \\
\hline & Tramea Hagen, 1861 & 0.54 & 0 & 1 & 1.28 & 0 & 18.4 & 0.95 & 151 & 152 \\
\hline $\mathbf{N}$ & & 182 & 183 & 365 & 388 & 597 & 750 & 839 & 2574 & 2,939 \\
\hline $\mathbf{S}$ & & 14 & 11 & 16 & 13 & 8 & 13 & 14 & 20 & 30 \\
\hline
\end{tabular}

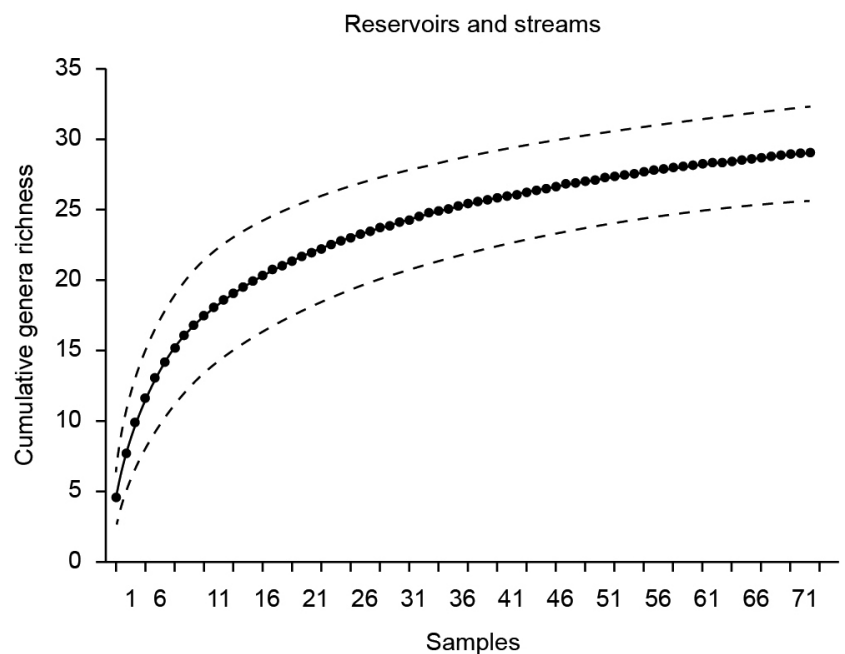

Figure 2. Cumulative richness of odonate larval genera in streams and farm ponds in the middle course of the Jacuí River basin, between March 2008 and February 2009.
$(10.9 \%)$ were dominant, comprising almost $75 \%$ of the specimens (Table 3$)$. Nine genera were rare and represented by no more than three individuals (Table 3). Four genera, Homeoura Kennedy, 1920, Macrothemis Hagen, 1868, Neoneura Selys, 1860, and Telagrion Selys, 1876 were found only as adults (Table 4).

Larvae of 20 genera were found in lentic environments and 16 in lotic environments (Table 3). Six genera were found in both environments, while 10 were exclusive to streams and 14 to farm ponds (Table 3 ). The rarefied curves confirmed that lentic environments should be richest than streams (Figure 3). In the farm ponds, Acanthagrion (30\%), Lestes (24.7\%), Erythrodiplax $(15.5 \%)$, and Oxyagrion (12.4\%) were the dominant genera, while in streams, Argia Rambur, 1842 (36.7\%), Navicordulia Machado e Costa, 1995 (20\%), and Hetaerina Hagen, 1853 (13.7\%) were the most abundant (Table 3). Adults of some genera were recorded in environments where their larval stages were not found. Adults of Argia, Brechmorhoga Kirby, 1894, and Hetaerina were found in lentic environments, but their larvae were found only in rivers and streams. Adults of Lestes were found in lotic environments, but their larvae occurred only in lentic sites (Table 3). 
Larval Odonata in streams and farm ponds from southern Brazil

Table 4. Diversity of odonate larvae and adults found in lentic and lotic environments of the middle course of the Jacuí River basin, RS, Brazil.

\begin{tabular}{|c|c|c|c|c|c|c|c|}
\hline \multirow[b]{3}{*}{ Family } & \multirow[b]{3}{*}{ Genera } & \multicolumn{4}{|c|}{ Larvae } & \multirow{2}{*}{\multicolumn{2}{|c|}{$\begin{array}{c}\text { Adults } \\
\text { 2008-2009 } \\
\end{array}$}} \\
\hline & & \multicolumn{2}{|c|}{ 2000-2002 } & \multicolumn{2}{|c|}{ 2008-2009 } & & \\
\hline & & Lentic & Lotic & Lentic & Lotic & Lentic & Lotic \\
\hline Calopterygidae & Hetaerina Hagen, 1853 & & $\mathrm{x}$ & & $\mathrm{x}$ & $\mathrm{x}$ & $\mathrm{x}$ \\
\hline \multirow[t]{7}{*}{ Coenagrionidae } & Acanthagrion Selys, 1876 & $\mathrm{x}$ & & $\mathrm{x}$ & $\mathrm{x}$ & $\mathrm{x}$ & $\mathrm{x}$ \\
\hline & Argia Rambur, 1842 & & $\mathrm{x}$ & & $\mathrm{x}$ & $\mathrm{x}$ & $\mathrm{x}$ \\
\hline & Homeoura Kennedy, 1920 & & & & & $\mathrm{x}$ & $\mathrm{x}$ \\
\hline & Ischnura Charpentier, 1840 & $\mathrm{x}$ & $\mathrm{x}$ & $\mathrm{x}$ & & $\mathrm{x}$ & $\mathrm{x}$ \\
\hline & Oxyagrion Selys, 1876 & $\mathrm{x}$ & & $\mathrm{x}$ & $\mathrm{x}$ & $\mathrm{x}$ & $\mathrm{x}$ \\
\hline & Telagrion Selys, 1876 & & & & & $\mathrm{x}$ & $\mathrm{x}$ \\
\hline & Telebasis Selys, 1865 & & & $\mathrm{x}$ & & $\mathrm{x}$ & \\
\hline Lestidae & Lestes Leach, 1815 & $\mathrm{x}$ & & $\mathrm{x}$ & & $\mathrm{x}$ & $\mathrm{x}$ \\
\hline \multirow[t]{2}{*}{ Megapodagrionidae } & Heteragrion Selys, 1862 & & $\mathrm{x}$ & & & & \\
\hline & Oxystigma Selys, 1862 & & $\mathrm{x}$ & & & & \\
\hline \multirow[t]{5}{*}{ Protoneuridae } & Epipleoneura Williamson, 1915 & & $\mathrm{x}$ & & & & \\
\hline & Forcepsioneura Lencioni, 1999 & $\mathrm{x}$ & & & & & \\
\hline & Neoneura Selys, 1860 & & & & & $\mathrm{x}$ & \\
\hline & Peristicta Hagen, 1860 & & $\mathrm{x}$ & & & & \\
\hline & Protoneura Selys, 1857 & $\mathrm{x}$ & & & & & \\
\hline \multirow[t]{5}{*}{ Aeshnidae } & Anax Leach 1815 & $\mathrm{x}$ & & $\mathrm{x}$ & & & \\
\hline & Castoraeschna Calvert, 1952 & & $\mathrm{x}$ & & $\mathrm{x}$ & & \\
\hline & Coryphaeschna Williamson, 1903 & & & $\mathrm{x}$ & & & \\
\hline & Remartinia Navás, 1911 & $\mathrm{x}$ & $\mathrm{x}$ & & & & \\
\hline & Rhionaeschna Förster, 1909 & $\mathrm{x}$ & & $\mathrm{x}$ & & & \\
\hline Corduliidae & Navicordulia Machado e Costa, 1995 & & $\mathrm{x}$ & & $\mathrm{x}$ & & \\
\hline \multirow[t]{6}{*}{ Gomphidae } & Aphylla Selys, 1854 & & & $\mathrm{x}$ & & & \\
\hline & Archaeogomphus Williamson, 1919 & & & & $\mathrm{x}$ & & \\
\hline & Desmogomphus Williamson, 1920 & & $\mathrm{x}$ & & $\mathrm{x}$ & & \\
\hline & Phyllocycla Calvert, 1948 & & $\mathrm{x}$ & & $\mathrm{x}$ & & $\mathrm{x}$ \\
\hline & Progomphus Selys, 1854 & & $\mathrm{x}$ & & $\mathrm{x}$ & & $\mathrm{x}$ \\
\hline & Tibiagomphus Belle, 1992 & & $\mathrm{x}$ & & $\mathrm{x}$ & & \\
\hline \multirow[t]{13}{*}{ Libellulidae } & Brechmorhoga Kirby 1894 & & $\mathrm{x}$ & & $\mathrm{x}$ & $\mathrm{x}$ & $\mathrm{x}$ \\
\hline & Elasmothemis Westfall, 1988 & $\mathrm{x}$ & $\mathrm{x}$ & $\mathrm{x}$ & $\mathrm{x}$ & & \\
\hline & Erythemis Hagen, 1861 & & & $\mathrm{x}$ & & & \\
\hline & Erythrodiplax Brauer, 1868 & $\mathrm{x}$ & $\mathrm{x}$ & $\mathrm{x}$ & $\mathrm{x}$ & $\mathrm{x}$ & $\mathrm{x}$ \\
\hline & Gynothemis Calvert in Ris, 1909 & & & $\mathrm{x}$ & & & \\
\hline & Macrothemis Hagen, 1868 & & & & & $\mathrm{x}$ & \\
\hline & Micrathyria Kirby, 1889 & $\mathrm{x}$ & & $\mathrm{x}$ & & $\mathrm{x}$ & \\
\hline & Oligoclada Karsch, 1890 & $\mathrm{x}$ & & $\mathrm{x}$ & & $\mathrm{x}$ & \\
\hline & Orthemis Hagen, 1861 & $\mathrm{x}$ & $\mathrm{x}$ & $\mathrm{x}$ & & $\mathrm{x}$ & \\
\hline & Pantala Hagen, 1861 & $\mathrm{x}$ & & $\mathrm{x}$ & $\mathrm{x}$ & $\mathrm{x}$ & $\mathrm{x}$ \\
\hline & Perithemis Hagen, 1861 & $\mathrm{x}$ & $\mathrm{x}$ & $\mathrm{x}$ & & $\mathrm{x}$ & $\mathrm{x}$ \\
\hline & Tauriphila Kirby, 1889 & $\mathrm{x}$ & & $\mathrm{x}$ & & & \\
\hline & Tramea Hagen, 1861 & $\mathrm{x}$ & & $\mathrm{x}$ & $\mathrm{x}$ & $\mathrm{x}$ & \\
\hline Number of ocurrences & & 18 & 19 & 20 & 16 & 19 & 14 \\
\hline
\end{tabular}

During the qualitative spatial and temporal wide term sampling (2000 to 2002), taxa not found during the quantitative collections were recorded: Heteragrion Selys, 1862, Oxystigma Selys, 1862 (Megapodagrionidae) Epipleoneura Williamson, 1915, Forcepsioneura Lencioni, 1999, Neoneura Selys, 1860, Peristicta Hagen, 1860, Protoneura Selys, 1857 (Protoneuridae) and Remartinia Navás, 1911 (Aeshnidae), as well as the families Megapodagrionidae and Protoneuridae (Table 4). Considering these additional specimens, the family Libellulidae contained most of the genera (13) found in the area studied, followed by Coenagrionidae (7) (Figure 4). Calopterygidae, Corduliidae and Lestidae were represented by only one genus each (Figure 4), Hetaerina, Navicordulia and Lestes, respectively. This evidences the occurrence of a total of 41 genera and nine families in the middle course of the Jacuí River basin, 30 in lentic and 27 in lotic environments (Table 4). 


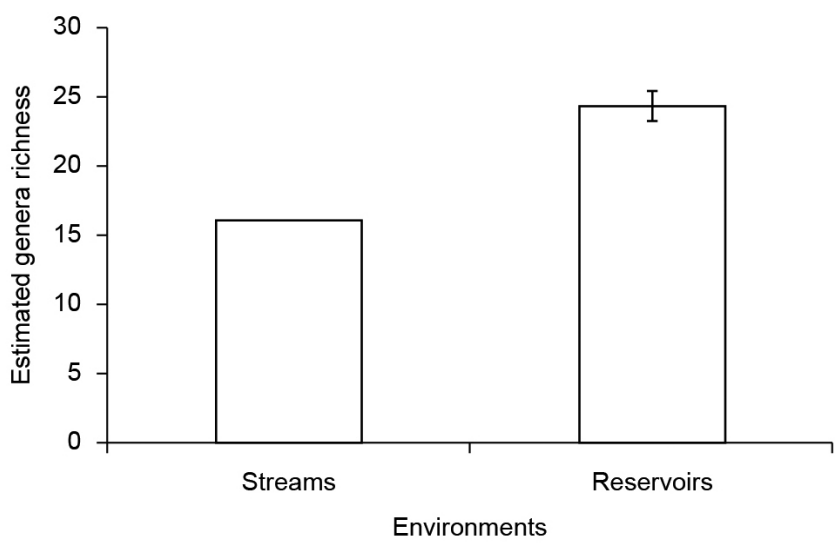

Figure 3. Estimated genera richness of odonate larval genera for each studied environment in the middle course of the Jacuí River basin, RS.

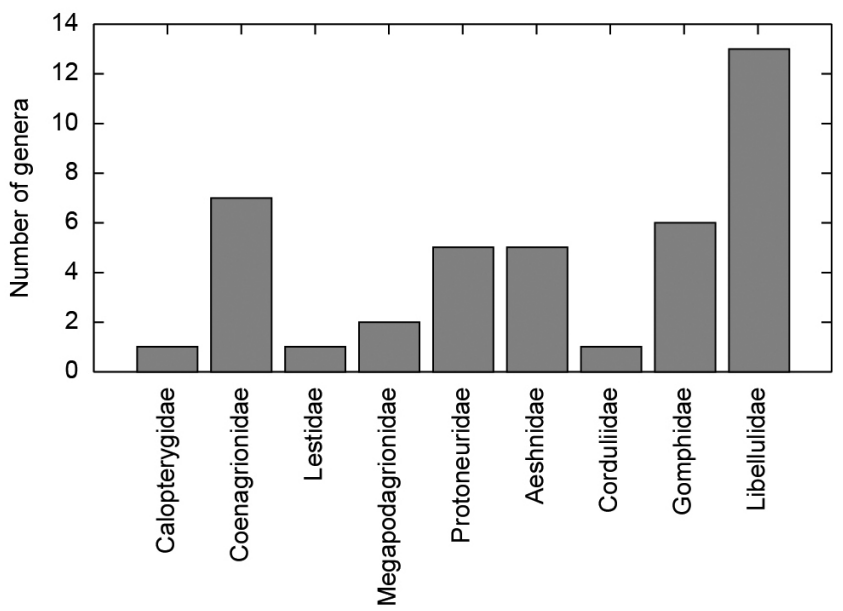

Figure 4. Number of genera, per odonate family, found in the middle Jacui River basin, RS, Brazil, during both quantitative and qualitative samplings.

\section{Discussion}

The richness of genera (30) found during the quantitative sampling (2008-2009) did not allow to assess the diversity of the studied area, as evidenced by the cumulative collector curve. In fact, when considering the additional, qualitative, samplings (20002002) conducted in a greater number of sites, comprehending more diversified environments, the richness increased to 37 genera. Adults captured in 2008-2009 also allowed the addition of four more genera to the overall diversity of the area. However, the spatial scale is also important for assessing the odonate diversity in the region. During the quantitative sampling, the lotic sites studied were restricted to medium order rivers. Small and great rivers were investigated only during the qualitative collections. Differences in river orders can influence the composition of odonate larval communities (Hawking \& New 1999). Besides, two streams could not be a sufficient number of sites to recognize the overall riverine odonate diversity. The four small ponds here investigated could also constitute an insufficient number of sites.

Previous studies (Costa 1971, Teixeira 1971, Maltchik et al. 2010) showed that ca. 37 odonate genera occur in Rio Grande do Sul. Our data, added to these, show that at least 50 odonate genera occur in the state. According to data concerning the geographic distribution of New World odonate genera (Garrison et al. 2006, Lencioni 2005, 2006), eight out of 41 genera found in the middle Jacuí River region are new records for the state: the anisopterans Archaeogomphus Williamson, 1919, Desmogomphus Williamson, 1920, Elasmothemis Westfall, 1988, Gynothemis Calvert in Ris, 1909 and Navicordulia, and the zygopterans Forcepsioneura Lencioni, 1999, Oxystigma Selys, 1862, and Protoneura Selys, 1857. Additionally, the southern limits of occurrence of Desmogomphus, Gynothemis, Navicordulia, Forcepsioneura, Oxystigma, and Protoneura were extended into temperate regions of the Neotropics.

Inventories conducted in both lentic and lotic environments simultaneously, in other locations of the Brazilian territory, have yielded values of richness ranging from 30 to 78 odonate genera (Carvalho \& Nessimian 1998, Ferreira-Peruquetti \& Fonseca-Gessner 2003, Anjos-Santos \& Costa 2006, Juen et al. 2007). Thus the overall diversity (41) of the area here studied can be considered generally lower than that recorded in warmer tropical/subtropical regions of the country. However, this difference is valid only for the streams analyzed (Assis et al. 2004, Anjos-Santos \& Costa 2006). The richness registered in the lentic sites of the middle Jacuí River was sometimes higher (De Marco Junior \& Latini 1998, De Marco Junior et al. 1999, Franco \& Takeda 2002, Fonseca et al. 2004, Fulan \& Henry 2006, 2007), and sometimes lower (Ferreira-Peruquetti \& Fonseca-Gessner 2003, Juen et al. 2007) than that recorded in other natural and artificial standing waters in the country.

Only ca. one-third (9) of the families recorded for the entire Neotropics (21, Kalkman et al. 2008) was found in the middle course of the Jacuí River. However, the pattern of their diversity in the Neotropical region (Kalkman et al. 2008) was maintained. Libellulidae was represented by the most genera, followed by Coenagrionidae and Gomphidae, whereas Calopterygidae, Corduliidae, and Lestidae were represented by only one genus each. The dominant genera in the study area, Acanthagrion, Oxyagrion, Erythrodiplax, and Lestes, have also been reported as dominant in other studies across western and southeastern Brazil. Members of Acanthagrion, for example, are abundant in lentic and lotic environments (Ferreira-Peruquetti \& De Marco Junior 2002, Franco \& Takeda 2002, Assis et al. 2004), and Oxyagrion may dominate in lakes and on floodplains (Fulan \& Henry 2006, Juen et al. 2007). Erythrodiplax also predominated in ponds and wetlands of central and southernmost Brazil (De Marco Junior et al. 1999, Maltchik et al. 2010). Dominance of Lestes in ponds was also reported for Argentinean grasslands (Ellenrieder 2009).

Richness and especially abundance were higher in farm ponds than in streams. Higher diversities of species in lentic habitats have also been reported in the northern hemisphere, in Europe and North America. These differences, in relation to lotic environments, have been attributed to characteristics such as higher colonization rates at lentic sites (Hof et al. 2006, Niba \& Samways 2006, Stevens \& Bailowitz 2009). Lentic environments tend to be geologically less predictable through time than lotic ones (Ribera et al. 2003). This geological attribute in lentic habitats presses species adapted to them to colonize them faster in order to be able to disperse and then persist (Hof et al. 2006).

The small farm ponds here studied, although artificial, generally present numerous macrophytes in their margins, a favorable environmental condition for the occurrence of odonates. Studies on reservoirs conducted in different parts of the world have shown that environmental features of both large and small reservoirs, such as age, area, vegetation structure (e.g., density and the proportion of the surface area covered) and water permanence (Tarr et al. 2005, for larvae; Kadoya et al. 2004, 2008, for adults) commonly influence the richness of odonate larvae (Oertli et al. 2002, Carchini et al. 2007, Maltchik et al. 2010). These features are also remarkably influenced 
by the origin and management of each reservoir, affecting the richness of odonate genera recorded in reservoirs (Kadoya et al. 2004, 2008, Ruggiero et al. 2008).

Known patterns of environmental preferences concerning lentic and lotic conditions were also maintained in the studied area, at both the family and genus levels. Calopterygidae, Corduliidae and Gomphidae predominated in lotic waters, Aeshnidae, Coenagrionidae, Libellulidae, Megapodagrionidae and Protoneuridae were found in both lentic and lotic environments, and Lestidae was recorded only in lentic settings, as previously found in other countries (Merritt \& Cummings 1996, Carvalho \& Nessimian 1998, Assis et al. 2004, Muzón et al. 2008, Ellenrieder 2009). Argia, Brechmorhoga, Hetaerina, Heteragrion and Navicordulia, and most genera of Gomphidae were found mostly in running waters. Acanthagrion and Erythrodiplax occurred in both running and standing waters, while Lestes, Oxyagrion and most aeshnid and libellulid genera were found in lentic environments, as in other localities (Merritt \& Cummins 1996, Carvalho \& Nessiman 1998, Ellenrieder 2000, 2007). The gomphid Aphylla Selys, 1854, found here in farm ponds, has also been recorded in lakes and ponds elsewhere (Merritt \& Cummins 1996).

Some adults were collected flying near different environments from those where their larvae were preferentially or exclusively found. These observations may be related to the proximity of many ponds to rivers or streams in the area. Argia and Lestes were found in Stream 2 and in Farm Pond 3, sites less than $1 \mathrm{~km}$ from each other. The same occurred with Brechmorhoga and Hetaerina, which were collected as adults in Farm Pond 1, a few meters from the main course of the Jacuí River.

\section{Final Remarks}

The richness of odonate genera in the streams and farm ponds of the middle Jacuí River region is lower than that registered in lotic and lentic systems of other Brazilian regions. The richness is lower even when streams are analyzed separately. The high richness previously recorded for other macroinvertebrate groups in rivers of regions with temperate climate, including the middle course of the Jacuí River basin (Floss et al. 2012) was not observed for odonates. This difference is possibly related to the temperate climate of the RS. Cold temperatures do not favor the occurrence of most taxa of odonates (Kalkman et al. 2008). Patterns of taxonomic diversity and the genera distribution, according to hydrological condition, follow those previously observed in the Neotropics. However, richness and especially abundance of odonates recorded in the studied area may be artificially inflated, because standing waters were originally scarce in the montane region where the middle Jacuí River runs. The small farm ponds of the region, although artificial, contain a variety of macrophytes, which allows the occurrence of an odonatofauna typical of lentic environments.

\section{Acknowledgements}

We are grateful to the late Dr. Luiz Onofre Irineu de Souza (UFSCar, São Carlos, São Paulo) and to MSc. Marina Schmidt Dalzochio (Unisinos, São Leopoldo, Rio Grande do Sul) for their availability and aid in larvae identification. We also thank MSc. Elzira Cecília Serafini Floss and biologist Edson Pinheiro Bachinski for helping with odonate sampling, and Aline Blank do Amaral for reviewing the manuscript.

\section{References}

ANJOS-SANTOS, D. \& COSTA, J.M. 2006. A revised checklist of Odonata (Insecta) from Marambaia, Rio de Janeiro, Brazil, with eight new records. Zootaxa 1300:37-50
ASSIS, J.C.F., CARVALHO, A.L. \& NESSIMIAN, J.L. 2004. Composição e preferência por microhábitat de imaturos de odonata (Insecta) em um trecho de baixada do Rio Ubatiba, Maricá-RJ, Brasil. Rev. Bras. Entomol. 48:273-282. http://dx.doi.org/10.1590/S0085-56262004000200017

BEISEL, J.N., USSEGLIO-POLATERA, P. \& MORETEAU, J.C. 2000. The spatial heterogeneity of a river bottom: a key factor determining macroinvertebrate communities. Hydrobiologia 422:163-171. http:// dx.doi.org/10.1023/A:1017094606335

BRASIL. Ministério das Minas e Energia. 1986. Projeto RADAMBRASIL. Levantamentos dos Recursos Naturais. Rio de Janeiro, 790p.

CARCHINI, G., BELLA, V.D., SOLIMINI, A.G. \& BAZZANTI, M. 2007. Relationships between the presence of odonate species and environmental characteristics in lowland ponds of central Italy. Ann. Limnol. - Int. J. Lim. 43:81-87. http://dx.doi.org/10.1051/limn/2007020

CARVALHO, A.L. \& CALIL, E.R. 2000. Chaves de identificação para as famílias de Odonata (Insecta) ocorrentes no Brasil. Adultos e larvas. Pap. Avulsos Zool. 41:223-241.

CARVALHO, A.L. \& NESSIMIAN, J.L. 1998. Odonata do estado do Rio de Janeiro, Brasil: hábitats e hábitos das larvas. In Ecologia de Insetos Aquáticos (J.L. Nessimian \& A.L. Carvalho, eds.). PPGE/UFRJ, Rio de Janeiro, Series Oecologia Brasiliensis, v.5, p.3-28.

CLAUSNITZER, V., KALKMAN, V.J., RAMC, M., COLLEN, B., BAILLIE, J.E.M., BEDJANIC, M., DARWALL, W.R.T., DIJKSTRA, K.D.B., DOWF, R., HAWKING, J., KARUBE, H., MALIKOVA, E., PAULSON, D., SCHUTTE, K., SUHLING, F., VILLANUEVAM, R.J., ELLENRIEDER, N.V. \& WILSON, K. 2009. Odonata enter the biodiversity crisis debate: the first global assessment of an insect group. Biol. Conserv. 142:1864-1869. http://dx.doi.org/10.1016/j. biocon.2009.03.028

COLWELL, R.K. 2009. EstimateS 8.2.0 for Windows. University of Connecticut, Connecticut.

CORBET, P.S. 1999. Behaviour and Ecology of Odonata. Comstock Pub Association, London.

COSTA, J.M. 1971. Contribuição ao conhecimento da fauna odonatológica do município de Santa Maria, Rio Grande do Sul. Atas Soc. Biol. Rio de Janeiro 14:193-194.

COSTA, J.M., SOUZA, L.O.I. \& OLDRINI, B.B. 2004. Chave para as famílias e gêneros das larvas de Odonata citadas para o Brasil: comentários e registros bibliográficos. Publ. Avul. Mus. Nac. 99:1-43.

DALZOCHIO, M.S., COSTA, J.M. \& UCHÔA, M.A. 2011. Diversity of Odonata (Insecta) in lotic systems from Serra da Bodoquena, Mato Grosso do Sul State, Brazil. Ver. Bras. Entomol. 55:88-94. http://dx.doi. org/10.1590/S0085-56262011000100014

DE MARCO JUNIOR, P. \& LATINI, A.O. 1998. Estrutura de guildas e riqueza de espécies em uma comunidade de larvas de anisoptera (Odonata). In Ecologia de Insetos Aquáticos (J.L. Nessimian \& A.L. Carvalho, eds.). PPGE/UFRJ, Rio de Janeiro, Series Oecologia Brasiliensis, v.5, p.101-112.

DE MARCO JUNIOR, P., LATINI, A.O. \& REIS, A.P. 1999. Environmental determination of dragonfly assemblage in aquaculture ponds. Aquac. Res., 30: 357-364.

DE MARCO JUNIOR, P. \& VIANNA, D.M. 2005. Distribuição do esforço de coleta de Odonata no Brasil - subsídios para escolha de áreas prioritárias para levantamentos faunísticos. Lundiana 6:13-26.

DURLO, M.A., MARCHIORI, J.N.C. \& LONGHI, S.J. 1982. Composição e estrutura da mata secundária no vale do rio Jacuí, RS. CeN. 4:129-139.

ELLENRIEDER, N.V. 2000. Species composition and temporal variation of odonate assemblages in the subtropical-pampasic ecotone, Buenos Aires, Argentina. Odonatologica 29:17-30.

ELLENRIEDER, N.V. 2007. Composition and structure of aquatic insect assemblages of Yungas mountain cloud forest streams in NW Argentina. Rev. Soc. Entomol. Argent. 66:57-76.

ELLENRIEDER, N.V. 2009. Odonata of argentinian Yungas cloud forest: distribution patterns and conservation status. Odonatologica 38:39-53. 
FERREIRA-PERUQUETTI, P.S. \& FONSECA-GESSNER, A.A. 2003. Comunidade de Odonata (Insecta) em áreas naturais do cerrado e monocultura no nordeste do estado de São Paulo, Brasil: relação entre o uso do solo e a riqueza faunística. Rev. Bras. Zool. 20:219-224. http:// dx.doi.org/10.1590/S0101-81752003000200008

FERREIRA-PERUQUETTI, P.S.F. \& DE MARCO JUNIOR, P. 2002. Efeito da alteração ambiental sobre comunidades de odonatas em riachos de mata atlântica de Minas Gerais, Brasil. Rev. Bras. Zool. 19:317- 327. http://dx.doi.org/10.1590/S0101-81752002000200002

FLOSS, E.C.S., KOTZIAN, C.B., SPIES, M.R., \& SECRETTI, E. 2012. Diversity of non-biting midge larvae assemblages in the Jacuí River basin, Brazil. J Insect Sci. 12:121. In press.

FONSECA, A.R., SANCHES, N.M., FONSECA, M.C., QUINTILHIANO, D.M. \& SILVA, E.S. 2004. Levantamento de espécies de Odonata associadas a tanques de piscicultura e efeito de Bacillus thuringiensis var. israelensis sobre ninfas de Pantala flavescens (Fabricius, 1798) (Odonata: Libellulidae). Acta Sci. Biol. Sci. 26:25-29.

FRANCO, G.M.S. \& TAKEDA, A.M. 2002. Spatial and temporal variation of Odonata larvae associated with macrophytes in two floodplain lakes from the upper Paraná River, Brazil. Acta Sci. Biol. Sci. 24:345-351.

FULAN, J.A. \& HENRY, R. 2006. The Odonata (Insecta) assemblage on Eichhornia azurea (Sw.) Kunth (Pontederiaceae) stands in Camargo Lake, a lateral lake on the Paranapanema River (state of São Paulo, Brazil), after an extreme inundation episode. Acta Limnol. Bras. 18:423-431.

FULAN, J.A. \& HENRY, R. 2007. Distribuição temporal de imaturos de Odonata (Insecta) associados a Eichhornia azurea (Kunth) na lagoa do Camargo, rio Paranapanema, São Paulo. Rev. Bras. Entomol. 51:224-227. http://dx.doi.org/10.1590/S0085-56262007000200013

GARRISON, R., ELLENRIEDER, N.V. \& LOUTON, J.A. 2006. Dragonfly genera of the new world: an illustrated and annotated key to the anisoptera. John Hopkins University Press, Baltimore.

GIACOMINI, H.C. \& DE MARCO JUNIOR, P. 2008. Larval ecomorphology of 13 libellulidae (Anisoptera, Odonata) of the middle Rio Doce valley, Minas Gerais, Brazil. Braz. J. Biol. 68:211-219. PMid:18470400. http:// dx.doi.org/10.1590/S1519-69842008000100031

GOTELLI, N.J. \& ENTSMINGER, G.L. 2006. EcoSim: null models software for ecology. version 7. Acquired Intelligence Inc. \& Kesey-Bear. Jericho, VT 05465. http://homepages.together.net/ gentsmin/ecosim.htm (ultimo acesso em 29/06/2010).

HAWKING, T.H. \& NEW, T.R. 1999. The distribution patterns of dragonflies (Insecta: Odonata) along the Kiewa River, Australia, and their relevance in conservation assessment. Hydrobiologia 392(2):249-260. http://dx.doi. org/10.1023/A:1003510514937

HOF, C., BRÄNDLE, M. \& BRANDL, R. 2006. Lentic odonates have larger and more northern ranges than lotic species. J. Biogeogr. 33:63-70. http:// dx.doi.org/10.1111/j.1365-2699.2005.01358.x

HURLBERT, S.H. 1971. The nonconcept of species diversity: a critique and alternative parameters. Ecology 52:577-585. http://dx.doi. org $/ 10.2307 / 1934145$

JUEN, L., CABETTE, H.S.R. \& DE MARCO JUNIOR, P. 2007. Odonate assemblage structure in relation to basin and aquatic habitat structure in Pantanal wetlands. Hydrobiologia 579:125-134. http://dx.doi. org/10.1007/s10750-006-0395-6

KADOYA, T., SUDA, S. \& WASHITANI, I. 2004. Dragonfly species richness on man-made ponds: effects of pond size and pond age on newly established assemblages. Ecol. Res. 19:461-467. http://dx.doi. org/10.1111/j.1440-1703.2004.00659.x

KADOYA, T., SUDA, S., TSUBAKI, Y. \& WASHITANI, I. 2008. The sensitivity of dragonflies to landscape structure differs between lifehistory groups. Landscape Ecol. 23:149-158. http://dx.doi.org/10.1007/ s10980-007-9151-1

KALKMAN, V.J., CLAUSNITZER, V., DIJKSTRA, K.D.B., ORR, A.G., PAULSON, D.R. \& TOL, J.V. 2008. Global diversity of dragonflies (Odonata) in freshwater. Hydrobiologia 595:351-363. http://dx.doi. org/10.1007/s10750-007-9029-x
LENCIONI, F.A.A. 2005. Damselflies of Brazil: an illustrated identification guide. I-Non-Coenagrionidae families. All Print, São Paulo.

LENCIONI, F.A.A. 2006. Damselflies of Brazil: an illustrated identification guide. II-Coenagrionidae. All Print, São Paulo.

LONGHI, S.J., DURLO, M.A. \& MARCHIORI, J.N.C. 1982. A vegetação da mata ribeirinha no curso médio do rio Jacuí, RS. C e N. 4:151-161.

MALUF, J.R.T. 2000. Nova classificação climática do estado do Rio Grande do Sul. Rev. Bras. Agrometeorol. 8:141-150.

MALTCHIK, L., STENERT, C., KOTZIAN, C.B. \& PIRES, M.M. 2010. Responses of odonate communities to environmental factors in southern Brazil wetlands. J. Kans. Entomol. Soc. 83:208-220. http://dx.doi. org/10.2317/JKES0910.13.1

MARCHIORI, J.N.C., LONGHI, S.J. \& DURLO, M.A. 1982. A vegetação de capoeira na região do curso médio do rio Jacuí, RS. C e N. 4:141-150.

MARCUZZO, S., PAGEL, S.M. \& CHIAPPETTI, M.I.S. 1998. A reserva da biosfera da mata atlântica no Rio Grande do Sul: situação atual, ações e perspectivas. Consórcio da Mata Attântica e Conselho Nacional da Reserva da Biosfera da Mata Atlântica, São Paulo.

McKIE, B.G., PEARSON, R.G. \& CRANTON, P.S. 2005. Does biogeographical history matter? Diversity and distribution of lotic midges (Diptera: Chironomidae) in the Australian Wet Tropics. Austral Ecol. 30:1-13. http://dx.doi.org/10.1111/j.1442-9993.2005.01408.x

MERRITT, R.W. \& CUMMINGS, K.W. 1996. An introduction to the aquatic insects of North America. Kendall/ Hunt, Iowa.

MUZÓN, J., ELLENRIEDER, N.V., PESSACQ, P., LOZANO, F., GARRÉ, A., LAMBRUSCHINI, J.A., RAMOS, L. \& WIEGEL-MUÑOZ, M.S. 2008. Odonata from Iberá wetlands (Corrientes, Argentina): preliminary inventory and biodiversity. Rev. Soc. Entomol. Argent. 67:59-67.

NERI, D.B., KOTZIAN, C.B. \& SIEGLOCH, A.E. 2005. Composição de Heteroptera aquáticos e semiaquáticos na área de abrangência da U.H.E.Dona Francisca, RS, Brasil: fase de pré-enchimento. Iheringia, Sér. Zool. 95:421-428.

NIBA, A.S. \& SAMWAYS, M.J. 2006. Remarkable elevational tolerance in an african Odonata larval assemblage. Odonatologica 35:265-280.

OERTLI, B., JOYE, D.A., CASTELLA, E., JUGE, R., CAMBIN, D. \& LACHAVANNE, J.B. 2002. Does size matter? The relationship between pond area and biodiversity. Biol. Conserv. 104:59-70. http://dx.doi. org/10.1016/S0006-3207(01)00154-9

PEREIRA, P.R.B., GARCIA NETTO, L.R., BORIN, C.J.A. \& SARTORI, M.G.B. 1989. Contribuição à geografia física do município de Santa Maria: unidades de paisagem. Geogr. Ens. Pesqui. 3:37-68.

RIBERA, I., FOSTER, G.N. \& VOGLER, A.P. 2003 Does habitat use explain large scale species richness patterns in aquatic beetles in Europe? Ecography 26:145-152.

RIO GRANDE DO SUL. Secretaria de Planejamento e Gestão do Estado do Rio Grande do Sul - SEPLAG. Atlas Socio-econômico do Rio Grande do Sul. www.scp.rs.gov.br/atlas (último acesso em 04/10/2013).

RUGGIERO, A., CÉRÉGHINO, R., FIGUEROLA, J., MARTY, P. \& ANGÉLIBERT, S. 2008. Farm ponds make a contribution to the biodiversity of aquatic insects in a french agricultural landscape. C. R. Biol. 331:298-308. PMid:18355753. http://dx.doi.org/10.1016/j. crvi.2008.01.009

SIEGLOCH, A.E., FROEHLICH, C.G. \& KOTZIAN, C.B. 2008. Composition and diversity of Ephemeroptera (Insecta) nymph communities in the middle section of the Jacuí River and some tributaries, southern Brazil. Iheringia, Sér. Zool. 98:425-432. http://dx.doi.org/10.1590/S007347212008000400002

SIMBERLOFF, D. 1972. Properties of the rarefaction diversity measurement. Am. Nat. 106:414-418. http://dx.doi.org/10.1086/282781

SOUZA, L.O.I., COSTA, J.M. \& OLDRINI, B.B. 2007. Odonata. In Guia online: Identificação de larvas de Insetos Aquáticos do Estado de São Paulo (C.G. Froehlich, ed.). http://sites.ffclrp.usp.br/aguadoce/Guia_online (último acesso em 17/01/2009). 
SPIES, M.R., FROEHLICH, C.G. \& KOTZIAN, C.B. 2006. Composition and diversity of Trichoptera (Insecta) larvae communities in the middle section of the Jacuí River and some tributaries, State of Rio Grande do Sul, Brazil. Iheringia, Sér. Zool. 96:389-398. http://dx.doi.org/10.1590/ S0073-47212006000400001

STEVENS, L.E. \& BAILOWITZ, R.A. 2009. Odonata Biogeography in the Grand Canyon ecoregion, southwestern USA. Ann. Entomol. Soc. Am. 102:261-274.

TARR, T.L., BABER, M.J. \& BABBITT, K.J. 2005. Macroinvertebrate community structure across a wetland hydroperiod gradient in southern New Hampshire, USA. Wet. Ecol. Manag. 13:321-334. http://dx.doi. org/10.1007/s11273-004-7525-6
TEIXEIRA, M.C. 1971. Contribuição para o conhecimento da fauna odonatológica do Rio Grande do Sul. Arq. Mus. Nac. 54:17-24.

VOELZ, N.J. \& McARTHUR, J.V. 2000. An exploration of factors influencing lotic species richness. Biodivers. Cons. 9:1543-1570. http://dx.doi. org/10.1023/A:1008984802844

WILLIAMS, P., WHITFIELD, M. \& BIGGS, J. 2008. How can we make new ponds biodiverse? A case study monitored over 7 years. Hydrobiologia 597:137-148. http://dx.doi.org/10.1007/s10750-007-9224-9

ZAMANILLO, E.A., TUCCI, C.E.M., SIMÕES-LOPES, M.O. \& LANNA, A.E. 1989. Management of navigation in the Jacuí river. Water Int. 14:181-192. http://dx.doi.org/10.1080/02508068908692103 